\title{
Asulam and Other Postemergence Herbicides for Sugarcane $^{1}$
}

\author{
Nelson Semidey and Luis Almodóvar ${ }^{2}$ \\ ABSTRACT
}

\begin{abstract}
Three herbicide experiments were conducted at the Lajas Research and Development Center to evaluate asulam (methyl sulfanilycarbamate) alone or in combination with other postemergence herbicides from 1980 to 1982 . In the first experiment with sugarcane cv. P.R. 1028, application of asulam at 3.25 $\mathrm{kg} / \mathrm{ha}$, preceded by an early postemergence application of metribuzin [(4amina-6-dimethyl)-3-methylihio-1,2,4-trianzin-5 (4H)-one] at $4.48 \mathrm{~kg} / \mathrm{ha}$, conIrolled weeds best ( $83 \%$ after 15 weeks) for the highest yield (218.4 tons cane/ha or 31.1 tons sugar/ha). Asulam alone (2.80 and $3.74 \mathrm{~kg}$ ai./ha) applied 5 weeks after planting was inferior in total weed control (59\% and $71 \%)$ and a lower yield was obtained $(111.8$ and 99.9 tons cane/ha or 13.0 and 12.1 tons sugar/ha, respectively). In the second experiment, with sugarcane cv. P.P. 980 , postemergence application of asulam $(3.74 \mathrm{~kg}$ ai./ ha) gave better control of grasses $(75 \%)$ when applied 4 weeks after planting than at 6 weeks $(68 \%)$. Asulam sprayed either 4 or 6 weeks after planting was not phytotoxic to sugarcane. In the third experiment, also with sugarcane cv. P.R. 980, dicamba (2-Methyl-3,6-Dichloro-o-anisic acid) at $0.56 \mathrm{~kg}$ ai./ha and Weedmaster ${ }^{\mathrm{n} 3}$ (a mixture of $10.3 \%$ dicamba $+29.6 \% 2-4, D$ ) at 2.34 and $4.68 \mathrm{~L} /$ ha gave excellent control of broadleaf weeds $(84 \%$ to $90 \%)$. These results were similar to those from the treatment with $2,4-\mathrm{D}(86 \%)$ and two handweedings $(89 \%)$. The vields obtained from herbicide treated plots (113.0 to 117.6 tons cane/ha) were inferior to those from hand-weeded check plots (160.1 tons cane/ha).
\end{abstract}

\section{INTRODUCTION}

Herbicides are essential components of cultural practices for sugarcane production in Puerto Rico and other countries. At present, there are several registered herbicides for the control of weeds in sugarcane (2). Evaluation of new herbicides is essential since many grasses and broadleaf weeds create severe problems in sugarcane plantations. Information on the use of herbicides is extensively available in the United States and other parts of the world $(4,5,6,7,8,9,10)$. Asulam has been especially effective for the control of grasses such as johnsongrass [Sorghum halepense (L.) Moench] in sugarcane $(4,5,8,10)$. Terbacil (3-tert-butyl-5cloro-6-methyluracil), fenac[(2,3,6-trichlorophenyl) acetic acid $]$ and trifluralin (a,a,a 6 -trifluoro-2-6-dinitro- $\mathrm{N}, \mathrm{N}$-dipropyl-p-toluidine) have been used commercially for preemergence control of itch-grass (Rott-

${ }^{1}$ Manuscript submitted to Editorial Board January 14, 1986.

${ }^{2}$ Research Assistant and Researcher in Weed Science, Crop Protection Department, Lajas Research and Development Center, Agricultural Experiment Station, University of Puerto Rico, Mayagüez Campus.

${ }^{3}$ Trade names in this publication are used only to provide specific information. Mention of a trade name does not constitute a warranty of equipment or materials by the Agricul tural Experiment Station of the University of Puerto Rico, nor is this mention a statement of preference over other equipment or materials. 
boellia exaltata L.f.) and several other weeds $(7,9)$. This study was conducted to evaluate asulam alone and in combination with other postemergence herbicides in order to improve selective weed control in sugarcane plantations.

\section{MATERIALS AND METHODS}

Three herbicide experiments were conducted at the Lajas Research and Development Center from 1980 to 1982. In the first experiment, sugarcane cv. P.R. 1028 was planted in a Vertisol (Udic Chromusterts, very fine, montmorillonitic, isohyperthermic) on April 8, 1980. Nine herbicide treatments were arranged in a randomized complete block design with four replications (table 1). Plots in all experiments measured $6.1 \times 6.1 \mathrm{~m}$ with four rows $1.5 \mathrm{~m}$ apart. Fertilizer $15-5-10$ at the rate of $896 \mathrm{~kg} / \mathrm{ha}$ was applied over the row immediately after planting sugarcane.

TABLE 1.-Herbicide trealments in sugarcane in 1980 (Experiment 1)

\begin{tabular}{lccllc}
\hline Initial treatment & Rate & $\begin{array}{c}\text { Weeks } \\
\text { after } \\
\text { planting }\end{array}$ & $\begin{array}{c}\text { Second } \\
\text { treatment }\end{array}$ & Rate & $\begin{array}{c}\text { Weeks } \\
\text { after } \\
\text { planting }\end{array}$ \\
\hline Asulam & kg ai./ha & & & $k g$ ai./ha & \\
Asulam & 2.80 & 5 & Asulam & 2.80 & 12 \\
Metribuzin & 3.74 & 5 & Asulam & 3.74 & 12 \\
Metribuzin & 2.24 & 3 & Asulam & 3.25 & 7 \\
Ametryn & 4.48 & 3 & Asulam & 3.25 & 7 \\
Diuron & 6.72 & 1 & Ametryn & 3.36 & 6 \\
Ametryn & 6.72 & 1 & Diuron & 3.36 & 6 \\
Hand-weeded check' & 6.72 & 3 & Ametryn/2,4-D & $3.36 / 1.12$ & 6 \\
Non-weeded check & & & & & \\
\hline
\end{tabular}

'Three hand-weedings were performed 3,6 and 12 weeks after planting.

In 1981-82 two experiments were conducted with sugarcane cv. P.R. 980. Sugarcane cuttings were planted August 4, 1981 in a randomized complete block design with six treatments and four replications in both experiments. This time fertilizer $16-4-4$ at the rate of $1086 \mathrm{~kg} / \mathrm{ha}$ was applied over the rows 3 weeks after planting. The second experiment included postemergence applications of asulam at 2.80 and $3.74 \mathrm{~kg}$ ai./ha on two different dates. The first treatment of asulam was 4 weeks after planting when sugarcane measured 25 to $30 \mathrm{~cm}$ in height. The second treatment of asulam was 6 weeks after planting when sugarcane reached 35 to $50 \mathrm{~cm}$ in height. Both asulam treatments were repeated 4 weeks after the initial application. A general application of 2,4-D at 1.12 $\mathrm{kg}$ ai./ha was sprayed to asulam-treated plots to control broadleaf weeds. 
Experiment 3 was conducted to evaluate banvel and Weedmaster ${ }^{\mathrm{rM}}$ for the control of broadleaf weeds tolerant to 2,4-D. Asulam at the rate of $2.80 \mathrm{~kg}$ ai./ha was also sprayed on treated plots to reduce grass weed competition. In all experiments herbicides were sprayed 4 weeks after planting with a handpump sprayer with a spray volume of $537 \mathrm{~L} / \mathrm{ha}$. Cultivated checks were hoed 4 and 8 weeks after planting. Weed control ratings and phytotoxicity evaluations were made at 8,13 and 15 weeks after planting in the 1980-81 experiments, and 8 and 11 weeks after planting in 1981-82. Percent weed control data were recorded on different dates by visual ratings of herbicide treated plots versus the non-weeded check. To record total control, an average control data for all weed species (sedges, grasses and broadleaves) was included. Total rainfall was $90.7 \mathrm{~cm}$ in the $1980-81$ experiment and $109.9 \mathrm{~cm}$ in 1981-82. Furrow irrigation was applied as needed in all experiments to supplement rainfall (1). Sugarcane plants were harvested approximately 12 months after planting. At harvest 10-cane samples from each plot were taken to determine sucrose content. Total cane yield from each plot (two inner rows) was determined, cane tonnage and sugar yields per hectare were calculated.

\section{RESULTS AND DISCUSSION}

\section{EXPERIMENT 1}

The predominant weed species in the experimental plots, listed in decreasing order of abundance were johnsongrass, crabgrass (Digitaria sanguinalis L.), ticklegrass (Pannicum trichoides Swatz.), junglerice [Echinochloa colonum (L.) Link], alexandergrass [Brachiaria plantaginea (Link) Hitchc.], morning glory [Ipomoea tiliacea (Willd.) Choisy] and purple nutsedge (Cyperus rotundus L.). Table 2 summarizes data on weed control at three different dates. An early postemergence application of metribuzin (4.48 kg ai./ha) followed by asulam $(3.25 \mathrm{~kg}$ ai./ha) gave the best weed control and yield (cane and sugar tonnage). Ametryn (6.72 kg ai./ha) in early postemergence application 1 or 3 weeks after planting and repeated at $3.36 \mathrm{~kg}$ ai./ha resulted in good weed control and yield. Standard diuron treatment was inefficient in weed control. Asulam treatments at 2.80 and $3.74 \mathrm{~kg}$ ai./ha applied 5 weeks after planting were inferior in total weed control and yield. Although asulam controlled grasses, including johnsongrass, sugarcane growth was severely affected by the initial weed competition. When metribuzin was applied early ( 3 weeks after planting) followed by asulam, sugarcane growth was not affected by weed competition. Data on cane yield is presented in Table 3. 
TABLE 2.- Lffect of herbicides on weed control at three different dates in 1980 (Experiment 1)

\begin{tabular}{|c|c|c|c|c|c|c|c|}
\hline \multirow{3}{*}{ Treatments } & \multirow{3}{*}{$\begin{array}{c}\text { Weeks after } \\
\text { planling }\end{array}$} & \multicolumn{6}{|c|}{ Weed control Averages $(\%)^{\prime}$} \\
\hline & & \multicolumn{2}{|c|}{8 weeks } & \multicolumn{2}{|c|}{13 weeks } & \multicolumn{2}{|c|}{15 weeks } \\
\hline & & GC & $\mathrm{TC}$ & GC & $\mathrm{TC}$ & $\mathrm{GC}$ & $\mathrm{TC}$ \\
\hline \multicolumn{8}{|l|}{ log ai./ha } \\
\hline Asulam (2.80) & 5 and 12 & 66 & 65 & 48 & 26 & 66 & 59 \\
\hline Asulam (3.74) & 5 and 12 & 74 & 68 & 47 & 38 & 78 & 71 \\
\hline Metribuzin (2.24)/Asulam (3.25) & 3 and 7 & 34 & 28 & 61 & 71 & 80 & 78 \\
\hline Metribuzin (4.48)/Asulam (3.25) & 3 and 7 & 55 & 43 & 76 & 81 & 85 & 83 \\
\hline Ametryn $(6.72+3.36)$ & 1 and 6 & 85 & 75 & 87 & 65 & 68 & 63 \\
\hline Diuron $(6.72+3.36)$ & 1 and 6 & 61 & 61 & 51 & 34 & 53 & 49 \\
\hline Ametryn $(6.72+3.36) / 2,4-\mathrm{D}(1.12)$ & 3 and 6 & 74 & 70 & 82 & 79 & 66 & 74 \\
\hline Hand-weeded check & 3,6 and 12 & 96 & 91 & 100 & 100 & 96 & 91 \\
\hline Non-weeded check & & 0 & 0 & 0 & 0 & 0 & 0 \\
\hline
\end{tabular}

I Mean ratings of four replications with 1 to 100 representing poor to excellent weed control. GC = Grass control; $T C=$ Total weed control.

TABLE 3.-Effect of herbicide applications on yield of sugarcane in 1980 (Experiment 1)

\begin{tabular}{|c|c|c|c|}
\hline \multirow[b]{2}{*}{ Trealments } & \multirow{2}{*}{$\begin{array}{l}\text { Weeks after } \\
\text { planting }\end{array}$} & \multicolumn{2}{|c|}{ Sugarcane yield ${ }^{1,2}$} \\
\hline & & $\begin{array}{l}\text { Tons } \\
\text { cane/ha }\end{array}$ & $\begin{array}{c}\text { Tons } \\
\text { sugar/ha }\end{array}$ \\
\hline \multicolumn{4}{|l|}{ lis ai./ha } \\
\hline Asulam (2.80) & 5 and 12 & $111.8 \mathrm{c}$ & $13.0 \mathrm{c}$ \\
\hline Asulam (3.74) & 5 and 12 & $99.9 \mathrm{c}$ & $12.1 \mathrm{c}$ \\
\hline Metribuzin 2.24/Asulam (3.25) & 3 and 7 & $153.7 \mathrm{~b}$ & $19.9 \mathrm{~b}$ \\
\hline Metribuzin (4.48)/Asulam (3.25) & 3 and 7 & $218.4 \mathrm{a}$ & $31.1 \mathrm{a}$ \\
\hline Ametryn $(6.72+3.36)$ & 1 and 6 & $157.5 \mathrm{~b}$ & $21.5 \mathrm{~b}$ \\
\hline Diuron $(6.72+3.36)$ & 1 and 6 & $129.2 \mathrm{bc}$ & $15.9 \mathrm{bc}$ \\
\hline Ametryn $(6.72+3.36) \mid 2,4-\mathrm{D}(1.12)$ & 3 and 6 & $185.9 \mathrm{~b}$ & $24.4 \mathrm{~b}$ \\
\hline Hand-weeded check & 3,6 and 12 & $181.4 \mathrm{~b}$ & $24.6 \mathrm{~b}$ \\
\hline Non-weeded check & $\longrightarrow$ & $2.2 \mathrm{~d}$ & $0.2 \mathrm{~d}$ \\
\hline $\mathrm{CV}(\%)$ & & 19.6 & 23.9 \\
\hline
\end{tabular}

'Yields in columns followed by the same letter do not differ significantly at the $5 \%$ probability level as determined by Duncan's multiple range test.

${ }^{2}$ Average of four replications in metric tons per heclare.

\section{EXPERIMENT 2}

Table 4 shows the efficacy of asulam treatments against predominant grass weeds. Asulam sprayed on two different growth stages at 2.80 and $3.74 \mathrm{~kg} / \mathrm{ha}$ rates was not toxic to sugarcane. Johnsongrass was the most predominant weed in the experimental plots with an average of 82 plants/ $\mathrm{m}^{2}$, followed by crabgrass, junglerice, and ticklegrass with 11,11 and 13 plants $/ \mathrm{m}^{2}$, respectively. Table 5 shows mean evaluation of plots. Asulam (3.74 kg ai./ha) followed by a single application of $2,4-\mathrm{D}$ gave good control 
TABLE 4.-Percentages of grass control by species after foliar treatment with asulam to sugarcane at two different growth stages (Experiment 2)

\begin{tabular}{|c|c|c|c|c|c|c|c|c|c|}
\hline \multirow{3}{*}{ Treatment $^{2}$} & \multirow{3}{*}{ Rate } & \multicolumn{8}{|c|}{ Weed control 8 and 11 weeks after planting $(\%)^{2}$} \\
\hline & & \multicolumn{2}{|c|}{ Sohnsongrass } & \multicolumn{2}{|c|}{ Crabgrass } & \multicolumn{2}{|c|}{ Ticklegrass } & \multicolumn{2}{|c|}{ Junglerice } \\
\hline & & 8 Weeks & 11 Weeks & 8 Weeks & 11 Weeks & 8 Weeks & 11 Weeks & 8 Weeks & 11 Weeks \\
\hline & \multicolumn{9}{|l|}{ kg ai./ho } \\
\hline Asulam & $2.80^{3}$ & 45 & 44 & 100 & 100 & 97 & 90 & 98 & 99 \\
\hline Asulam & $3.74^{3}$ & 91 & 64 & 100 & 100 & 100 & 100 & 99 & 100 \\
\hline Asulam & $2.80^{4}$ & 15 & 20 & 100 & 100 & 56 & 100 & 78 & 94 \\
\hline Asulam & $3.74^{4}$ & 17 & 76 & 100 & 99 & 36 & 100 & 76 & 98 \\
\hline Hand-weeded check & & 98 & 89 & 100 & 100 & 100 & 100 & 100 & 100 \\
\hline Non-weeded check & & $(82)^{5}$ & - & $(11)^{5}$ & - & $(13)^{5}$ & - & $(11)^{5}$ & - \\
\hline
\end{tabular}

I 2,4-D was applied to asulam-treated plots 4 weeks after planting sugarcane.

${ }^{2}$ Mean ratings of four replications with 1 to 100 representing poor to excellent weed control.

${ }^{3}$ Sugarcane $25-30 \mathrm{~cm}$ in height 4 weeks after planting.

- Sugarcane $35-50 \mathrm{~cm}$ in height 6 weeks after planting.

${ }^{5}$ Average number of plants $/ \mathrm{m}^{2}$. 
of grasses when applied 4 weeks after planting. The application of asulam at $2.80 \mathrm{~kg} / \mathrm{ha}$ was inefficient against johnsongrass since regrowth of this grass took place. During the 1980 experiment, johnsongrass control was improved with an early application of metribuzin. Our results in 1981 suggest the need of one preemergence or early postemergence treatments with a standard herbicide in order to reduce weed population before the application of asulam.

Table 6 shows data on cane yield and sugar production. Hand weeded check resulted in the highest yields, but not significant differences were observed when compared with asulum at $3.74 \mathrm{~kg}$ ai./ha applied four weeks after planting. All herbicide treatments contributed to good sugar yield when compared with non-weeded check.

TABLE 5.-Effect of asulam treatments on the control of weeds in sugarcane in 1981 (Experiment 2)

\begin{tabular}{|c|c|c|c|c|c|}
\hline \multirow{3}{*}{ Treatment' } & \multirow{3}{*}{ Rate } & \multicolumn{4}{|c|}{$\begin{array}{c}\text { Average weed control } 8 \text { and } 11 \text { weeks after } \\
\text { planting }\end{array}$} \\
\hline & & \multicolumn{2}{|c|}{ Grass control } & \multicolumn{2}{|c|}{ Total weed control } \\
\hline & & 8 Weeks & 11 Weeks & 8 Weeks & 11 Weeks \\
\hline & kg ai./he & & & & \\
\hline Asulam & $2.80^{3}$ & 65 & 51 & 58 & 56 \\
\hline Asulam & $3.74^{3}$ & 87 & 75 & 91 & 76 \\
\hline Asulam & $2.80^{4}$ & 25 & 29 & 28 & 39 \\
\hline Asulam & $3.74^{4}$ & 15 & 68 & 15 & 75 \\
\hline Hand-weeded check & & 96 & 96 & 94 & 95 \\
\hline Non-weeded check & & 0 & 0 & 0 & 0 \\
\hline
\end{tabular}

12,4-D was applied to asulam-treated plots 4 weeks after planting sugarcane.

${ }^{2}$ Mean ratings of four replications with 1 to 100 representing poor to excellent weed control.

${ }^{3}$ Sugarcane $25-30 \mathrm{~cm}$ in height 4 weeks after planting.

4 Sugarcane $35-50 \mathrm{~cm}$ in height 6 weeks after planting.

\section{EXPERIMENT 3}

This experiment was conducted to evaluate herbicides for the control of broadleaf weeds in sugarcane which are not efficiently controlled by 2,4-D. Grass weed species were similar to those in experiment 2. Broadleaf weeds comprised only $30 \%$ of the total weed population. The most abundant species were morning glory, niruri (Phyllanthus niruri L.), spurge (Euphorbia heterophylla L.) and wirebush (Melochia pyramidata L.). All herbicide treatments showed excellent control of these broadleaf weeds, very similar to hand-weeded check (table 7). Table 8 shows data on tonnage of cane and sugar yield. None of the herbicide treatments were better than hand-weeded checks in cane tonnage or sugar yield. 
TABLE 6.-Effect of asulam trealments on sugarcane yield in 1981-82 (Experiment 2)

\begin{tabular}{|c|c|c|c|c|}
\hline \multirow[b]{2}{*}{ Treatment } & \multirow[b]{2}{*}{ Rate } & \multirow{2}{*}{$\begin{array}{l}\text { Weeks } \\
\text { alter } \\
\text { planting }\end{array}$} & \multicolumn{2}{|c|}{ Sugarcane yield ${ }^{1.2}$} \\
\hline & & & $\begin{array}{c}\text { Tons } \\
\text { cane/ha }\end{array}$ & $\begin{array}{c}\text { 'Tons } \\
\text { sugur/ha }\end{array}$ \\
\hline & \multicolumn{4}{|c|}{ lig ai./ha } \\
\hline Asulam & 2.80 & 4 and 8 & $111.1 \mathrm{~b}$ & $9.4 \mathrm{~b}$ \\
\hline Asulam & 3.74 & 4 and 8 & $135.7 \mathrm{ab}$ & $13.2 \mathrm{ab}$ \\
\hline Asulam & 2.80 & 6 and 10 & $116.5 \mathrm{~b}$ & $9.8 \mathrm{ab}$ \\
\hline Asulam & 3.74 & 6 and 10 & $128.8 \mathrm{~b}$ & $10.5 \mathrm{ab}$ \\
\hline Hand-weeded check & & 4 and 6 & 158.1 a & $15.1 \mathrm{a}$ \\
\hline Non-weeded check & & - & $56.4 \mathrm{c}$ & $3.7 \mathrm{c}$ \\
\hline $\mathrm{CV}(\%)$ & & & 14.1 & 24,5 \\
\hline
\end{tabular}

${ }^{1}$ Yields in columns followed by the same letter do not differ significantly at the $5 \%$ probability level as determined by Duncan's multiple range test.

${ }^{2}$ Average of four replications in metric tons per hectare.

TABLE 7.-Effect of broadleaf weed killers and asulam on the control of weeds in surarcane in 1981 (Experiment 3)

\begin{tabular}{|c|c|c|c|c|c|c|c|}
\hline \multirow{3}{*}{ Treatment } & \multirow{3}{*}{ Rate/ha } & \multicolumn{6}{|c|}{ Weed control 8 and 11 weeks after planting (\%)' } \\
\hline & & \multicolumn{2}{|c|}{ Broadleaf } & \multicolumn{2}{|c|}{ Grasses $^{2}$} & \multicolumn{2}{|c|}{ Total control } \\
\hline & & 8 Weeks & 11 Weeks & g Weeks & 11 Weeks & 8 Weeks & 11 Weeks \\
\hline Weedmaster ${ }^{(9)}$ & $2.34 \mathrm{~L}$ & 100 & 85 & 84 & 58 & 81 & 69 \\
\hline Weedmaster & $4.68 \mathrm{~L}$ & 100 & 90 & 81 & 64 & 83 & 71 \\
\hline Dicamba & $0.56 \mathrm{~kg}$ ai. & 94 & 84 & 58 & 51 & 68 & 61 \\
\hline $2-4 \mathrm{D}$ & $1.12 \mathrm{~kg}$ ai. & 97 & 86 & 79 & 58 & 78 & 61 \\
\hline Hand-weeded check & & 98 & 89 & 3.) & 95 & 94 & 95 \\
\hline Non-weeded check & & 0 & 0 & 0 & 0 & 0 & 0 \\
\hline
\end{tabular}

' Average of four replications with 1 to 100 representing poor to excellent weed control.

${ }^{2}$ Asulam at the rate of $2.8 \mathrm{~kg} / \mathrm{ha}$ was applied 4 weeks after planting sugarcane.

TABLE 8-Effect of broadleaf weed killers and asulam on sugarcane yield in 1981-82 (Experiment 3)

\begin{tabular}{llcc}
\hline \multirow{2}{*}{ Treatment } & Rate/ha & \multicolumn{2}{c}{ Sugarcane yield..2 } \\
\cline { 3 - 4 } & & $\begin{array}{c}\text { Tons } \\
\text { cane/ha }\end{array}$ & $\begin{array}{c}\text { Tons } \\
\text { sugar/ha }\end{array}$ \\
\hline Weedmaster & & $113.0 \mathrm{~b}$ & $10.1 \mathrm{a}$ \\
Weedmaster & $2.34 \mathrm{~L}$ & $113.0 \mathrm{~b}$ & $9.8 \mathrm{a}$ \\
Dicamba & $4.68 \mathrm{~L}$ & $117.6 \mathrm{~b}$ & $10.2 \mathrm{a}$ \\
2-4-D & $0.56 \mathrm{~kg}$ ai. & $105.9 \mathrm{~b}$ & $10.9 \mathrm{a}$ \\
Hand-weeded check & $1.12 \mathrm{~kg} \mathrm{ai}$. & $160.1 \mathrm{a}$ & $15.1 \mathrm{a}$ \\
Non-weeded check & & $57.7 \mathrm{c}$ & $3.7 \mathrm{~b}$ \\
CV (\%) & & 8.4 & 38.9 \\
\hline
\end{tabular}

${ }^{2}$ Yields in columns followed by the same letter do not differ significantly at the $5 \%$ probability level as determined by Duncan's multiple range test.

${ }^{2}$ Average of four replications in metric tons per hectare. 
Sugarcane yield obtained on hand-weeded check plots were on the expected range (3). Application rates of $2.80 \mathrm{~kg} / \mathrm{ha}$ of asulam seem to be inadequate for grass weed control. The high population of johnsongrass not completely controlled by asulam reduced the effectiveness of the herbicides under study and this turn contributed to lower sugarcane yields.

\section{RESUMEN}

En el Centro de Investigación y Desarrollo de Lajas se hicieron en 1980 y 1981-82 tres experimentos con caña de azúcar para evaluar el herbicida asulam solo y en combinación con otros herbicidas. El mejor control de malezas y rendimientos de la caña, tanto en tonelaje de caña como en azúcar producida, se logró en 1980 con una aplicación posemergente temprana de $4.48 \mathrm{~kg}$ ia./ha de metribuzin seguida por una de $3.25 \mathrm{~kg} \mathrm{ia}$./ ha de asulam. Con asulam aplicado solo, a 2.80 y $3.74 \mathrm{~kg}$ ia. $/ \mathrm{ha}, 5$ semanas después de sembrar la caña, no se controlaron las malezas ni el rendimiento de la caña fue bueno. En uno de los experimentos del 198182 , la aplicación posemergente de $3.74 \mathrm{~kg}$ ai./ha de asulam controló mejor las malezas cuando se aplicó 4 semanas después de sembrar que cuando se aplicó a las 6 semanas. El asulam aplicado a las 4 ó 6 semanas después de sembrar no fue tóxico para la caña. En otro de los experimentos de 1981-82 se evaluaron los herbicidas dicamba y Weedmaster ${ }^{\mathrm{m}}$ para controlar las malezas de hoja ancha que toleran el 2,4-D. Con $0.56 \mathrm{~kg}$ ia./ha de dicamba y 2.34 y $4.68 \mathrm{~L} / \mathrm{ha}$ de Weedmaster ${ }^{\mathrm{m}}$ se logró controlar excelentemente las malezas de hoja ancha, un control muy similar al de 2,4-D y 2 desyerbos. Los rendimientos de caña obtenidos con estos herbicidas fueron inferiores a los del testigo desyerbado. Estos rendimientos más bajos pueden atribuírsele al control inadecuado de la yerba johnson (Sorghum halepense) del asulam, el cual se aplicó en forma general en todas las parcelas a las que se les aplicaron los tratamientos de herbicidas.

\section{LITERATURE CITED}

1. Anonymous, 1976. Conjunto tecnológico para la producción de caña de azúcar. Esta. Exp. Agric. Univ. P.R. Publ. 103.

2. Anonymous, 1976. Control químico de las malas yerbas en los cultivos económicos de Puerto Rico. Esta. Exp. Agric. Univ, P.R. Publ. 89.

3. Anonymous, 1983. Facts and Figures on Puerto Rico's Agriculture 1981-82/1982-83. Commonwealth of Puerto Rico, Department of Agriculture. Santurce, Puerto Rico.

4. Cooke, K., C. G. Parker and D. J. Williams, 1969. Postemergence weed control experiments in sugarcane with formulations of asulam and ioxynil/2,4-D. Proc. West Indies Sugar Technol. p. 112-117.

5. Ibrahim, A. A. S., 1982. Efficiency of some herbicides for weed control in sugarcane. Trop. Pest Manage. 28: 255-58. 
6. Williams, D. J. and G. B. Hornail, 1972. Asulam for johnsongrass control in non-crop situations. Proc. South. Weed Sci. Soc. 25: 347-53.

7. Millhollon, R. W., 1972. Suil-incorporated trifluralin for controlling weeds in sugarcane. Proc. Am. Soc. Sugar Cane Technol. 2: 41-4.

8. __, 1976. Asulam for johnsongrass control in sugarcane. Weed Sci. 24:496-99.

9. - 1983. Late-season weed control in sugarcane with herbicides applied at lay-by. J. Am. Soc. Sugar Cane. Technol. 2; 17-21.

10. Tuckett, M. J. and R. W. E. Ball, 1968. Weed control in sugarcane with asulam. Proc. Br. Weed Control Conf. 9: 744-49. 